DOI: $10.20472 / S S .2015 .4 .4 .001$

\title{
THE SOCIOLOGY OF WEB 2.0
}

\section{SAIDA KHEIRA BENAMMAR}

\begin{abstract}
:
Web 2.0 starts from people to people, a user is the producer of digital content and he is the consumer of it interchangeably with other users and it is not necessarily for all users to be producers, some of them settle for only browsing the web, also the web create social relationship between users like online relationship or maintain other offline relationship, in this part we will introduce an initiation in the sociology of web2.0 or social web to identify what is social in social web? And how social web changes social relationship between individuals.

Social web is a platform that functions to connect people and facilitate communication, collaboration and participation for them within a relations network characterized through a set of communicative tools and applications called web2.0 applications represented in blogs, social networks sites, wikis, discussion forum, micro blogging...etc... they call it social web because it connects people and help them to build communities and create or maintain offline/online relationship, where Christian Fuchs indicates that:"social networks platforms (we will detailed in another chapter) is the ideal example expressing what is termed web2.0, that it enable maintaining and building social relationship". Adding:"web2.0 applications like social networking platforms keep individuals busy generating personal information that they display online in social networking profiles, blogs..Etc, most of these application are built in such way that each participant has his/her own space that he/she creates and maintains.
\end{abstract}

\section{Keywords:}

web 2.0, Networks, social capital

JEL Classification: Z00, Z10

\section{Authors:}

SAIDA KHEIRA BENAMMAR, University of Mostaganem, Algeria, Algeria, Email: souadbenammar@hotmail.com

\section{Citation:}

SAIDA KHEIRA BENAMMAR (2015). The sociology of web 2.0 . International Journal of Social Sciences, Vol. IV(4), pp. 1-15., 10.20472/SS.2015.4.4.001 


\section{Introduction:}

The emergence of web 2.0 is associated to the emergence of applications and online sites that allow to individuals the participation and the contribution in creating internet content, here users have shifted from the read web (consumption) to the read-write web (production).

The term web2.0 has created a huge discussion it stills ambiguous till now between what is and what is not web 2.0? Some scholars consider it as a revolution in the world of the internet and others see it as a tool of marketing and advertising when the use of the term became ubiquitous, a search in Google about it for example, retrieved about 124.000.000 results at the time of writing and entering it into the still experimental Google trends (www.google.com/trends) ${ }^{1}$

This term coined by Tim O'Reilly in 2004 in a brainstorming discussion between O'Reilly media and Media live company about the potential future conference about the web. Where Dale Dougherty (member in O'Reilly) suggests that the web after the Dot-com crash (2001) was more important than ever, the new websites and applications have something in common using new technologic amelioration ${ }^{2}$, after that Tim O'Reilly published an article subtitle "What is web 2.0?" in his blog introducing the main principles that found web 2.0.

We cannot talk about a unique clear definition to define the concept of the web2.0 because of the ambiguity as well as the different opinion of researchers and scholars around it; whether it really reflects a revolution in the world of online communication, or is it just an advertising machine.

\section{1-Web 2.0 as a tool of communication and participation:}

Web 2.0 or social web defined as:"a set of tools that enable group forming networks to emerge quickly. It includes numerous media, utilities and applications that empower individual efforts, link individuals together into

Larger aggregates interconnect groups, provide metadata about network dynamics, flows, and traffic, allowing social networks to form, clump, become visible, and be measured, tracked and interconnected". 3

This definition describe the web 2.0 as a tool for cooperating and participation in producing digital content and the ability to create relationship and build social networks that connect users through a set of applications that allowed those actions.

\footnotetext{
1 David Beer, Roger Burrows, Sociology and, of and in web 2.0 : some initial considerations, http://www.socresonline.org.uk/12/5/17.html, seen in 18/02/2015, 19:44.

2 Thomas Chaimbault, Web 2.0 :l'avenir du web, 2007, école nationale supérieure des sciences de l'information et des bibliothèques, $\mathrm{p} 2$.

${ }^{3}$ Christian Fuchs, internet and society (social theory in the information age), New York: Routledge. 2008, p102.
} 
As the definition of Sara M.Long clarifies, web 2.0 is a term that refers to the second generation of advanced web tools, including social networking sites, blogs, and the like. Web 2.0 has created a forum for sophisticated social interaction and collaboration online, and a complex internet culture is emerging in which many young adults, including college students participate, they communicate with many people their lives via the internet and they often use the internet at work and at school. ${ }^{1}$

Researchers agree that the most illustrative examples about web 2.0 are those applications that have appeared and grow as fast on the era of the web, like blogs social networks sites, wikis, RSS ...etc.

Wikipedia is perhaps the leading example of how this type of open and collaborative practice operates to create an online repository of ideas and knowledge formed into a dynamic document that changes from day to day. Here users are involved as producers and consumers of the information, both browsing for and adding content to the project. ${ }^{2}$

The web characterized in two main points, Read web (web1.0) and Read_Write web (wev2.0), the act of reading and writing associated to the acts of users in the internet. A user in web1.0 was only receiving and reading information while the web2.0 enables him to read and write that means transition from consumption to production. Thus, the $\mathrm{read} / \mathrm{write}$ web was truly born again. We could all write, not just read, in ways never before possible. For the first time in history, at least in the developed world, anyone with a computer and internet connection could own a press. Just about anyone could make the news, ${ }^{3}$ expressed the possibility of publishing news and information on the web through a variety and multiple applications.

\section{2-web 2.0 as a tool of marketing and advertising:}

On the other hand, some scholars opposed that the idea of web2.0 as a second phase of developed communication in the internet for them the creation of the first web was for communication and participation and that the web2.0 is such an ideology of marketing to increase investment in the web and survive the Dot_Com crash (2001) searching for a profit model in the internet.

Christian Fuchs considers the web2.0 as a marketing ideology that the notion of participation underlying web2.0 is only pseudo participation, that web2.0 is dominated by large corporation's commercial interests that it is an advertising machine, that communication and community building has also been supported by older internet applications. $^{4}$

\footnotetext{
${ }^{1}$ Sarah M. Long, Exploring Web 2.0: The Impact of Digital Communications Technologies on Youth Relationships and Sociability, 2010, sociology student scholarship,

http://scholar.oxy.edu/sociology_student/2/?utm_source=scholar.oxy.edu\%2Fsociology_student\%2F2\&utm_mediu m=PDF\&utm_campaign=PDFCoverPages, seen in: 09/02/2015, 23:23.

2 David beer \& Roger burrows, Opcit.

3 Dan Gillmor, We the media (grassroots journalism by the people, for the people), O'Reilly, USA, 2006, p24.

${ }^{4}$ Christian Fuchs, New Media, web2.0 and surveillance, Sociology compass, (5/2), 2011, p137.
} 
Business men were searching to create a business model in the internet to gain money especially after the fall down of dot.com project as some researcher introduces the web 2.0 like an answer to the question:"How we gain money with the new web technologies?

The founder of the web Sir Tim Berners-Lee criticizes the web 2.0 and considers it as an ambiguous term having no identification nor meaning, and about the deference between web1.0 and web2.0 when he was asked in an interview for a podcast published on IBM's website, whether web2.0 was deferent to what might be called web1.0 because the former is all about connecting people, he replied:

"Totally no, web1.0 was all about connecting people. It was an interactive space and I think web2.0 is of course a piece of jargon, nobody even knows what it means. If web2.0 for you is blogs and wikis, this web2.0 is people to people. But that was the web was supposed to be all along, and in fact, you know, this web2.0, it means using the standards which have been produced by all these people working on web1.0". ${ }^{1}$

\section{3-What happened in the technical side?}

At the technical level some technical units of AJAX that have been contributed to make the Web faster and better with the help of other technicians (XML, HTML, CSS and Java script).

The Distribution of services and web applications was driving through the widespread adoption of a set of techniques that date back to the term AJAX (asynchronous JavaScript $+\mathrm{XML}$ ) this term was coined by Jesse James Garrett. Before that users of

HTML sites suffering of waiting the pages to load and re-load when they click on a particular option in the hyperlink. ${ }^{2}$

Ajax technique facilitate browsing and communicating in the web where users after have been able to upload and reload pages that contribute in the flow of more information.

Web1.0 predominantly, although not exclusively, involved hierarchically arranged websites with information largely controlled by a small group of content providers. Most users browsed, read, and obtained information and were directed through a site from a common entry point or front page. Individuals with programming expertise in hypertext markup language (HTML) could post content, but web 1.0 accommodated only modest individual knowledge creation and sharing, mostly through primarily text_based online forums and archives lists. ${ }^{3}$

\section{4-Sociality of social web:}

\footnotetext{
${ }^{1}$ Paul Anderson, what is web2.0? (ideas, technologies and implications for education), JISC technology and standards watch, 2007, p5

2 lbid, p27.

${ }^{3}$ Christine Greenhown and all, .web2.0 and classroom research: what path should we take now?, American educational researcher association \& sage, 38, may2009, p247.
} 
Social web is a platform that functions to connect people and facilitate communication, collaboration and participation for them within a relation's network characterized through a set of communicative tools called web2.0 applications represented in blogs, social networks sites, wikis, discussion forums, micro blogging.....etc. They call it social web because it connects people and helps them to build communities and create or maintain offline/online relationship, where Christian Fuchs indicates that:"social network platforms are the ideal example expressing what is termed web2.0, that it enables maintaining and building social relationship". ${ }^{1}$ Adding :"web2.0 applications like social networking platforms keep individuals busy generating personal information that they display online in social networking profiles and blogs....etc. Most of these applications are built in such way that each participant has his/her own space that he/she creates and maintains it. ${ }^{2}$

Discussing the social in social web conduct us to search about the meaning of (social) according to social theories and approaches that have discussed this concept in sociology grounds, starting with Emile Durkheim (social facts), Max Weber (social interaction) to Karl Marx (co_operation) and TÖnnies (community building), so we have three social acts beginning with cognition then communication arriving to cooperation and those three acts are the three basic features of the web 1,2 , and 3 .

\section{${ }^{\star}$ Cognition as a social fact:}

The concept of cognition is relatively associated to the main feature of web 1.0 where users are only receiver of the information and browser of the web content without having the possibility to create any kind of content. For some scholars they claim that web 1.0 does not represent any social act because they consider what is sociality is related with social interaction between individuals, but returning to Durkheim's notion of social fact we can say that web1.0 is social according to the notion of (SOCIAL) in Durkheim understanding. In chapter one of his book (Rules of sociological method), Durkheim defines social fact as: "any way of acting whether fixed or not, capable of exerting over the individual an external constraint" or "which is general over the whole of a given society whilst having an existence of its own independent of its individual manifestations". ${ }^{3}$ In Another definition he said :" .......manners of acting, thinking and feeling external to the individual, which are invested with a coercive power by virtue of which they exercise control over him". 4

In order to distinguish sociology as an autonomous discipline distinct from the sciences of biology and psychology, which have their own separable subject matters". 5 For Durkheim there is deference between individual behavior that took a place in the internal feelings which are the subject of psychology and the individual behavior which exists in

\footnotetext{
${ }^{1}$ Christian Fuchs, information and communication technologies and society ( a contribution to the critique of the political economy of the internet), Sage, European journal of communication, 24(1), 2010, p80.

${ }^{2}$ lbid, p84.

${ }^{3}$ Emile Durkheim, rules of sociological method, translated by: W.D. Halls, The free press, 1982, p59.

${ }^{4}$ John D. Greenwood, Social facts, social groups and social explanation, NOÛS, 37:1 (2003), p94.

5 lbid, p94.
} 
external feelings and took place in sociology. A behavior is social behavior if and only if it is engaged in by an individual because and on condition that other members of a social group are represented as engaging in that (or another) social behavior in similar conditions. ${ }^{1}$

According to Durkheim's concept of social facts, any act is social therefore any individual activity on the web is social, a social fact is every way of acting which is general throughout a given society, while at the same time existing in its own right independent or its individual manifestations. ${ }^{2}$ For Durkheim a social fact I a social form of cognition, emotion or behavior. ${ }^{3}$

\section{*The web from cognition to communication:}

On the contrary of Durkheim's concept we found Weber's understanding for social is what connects the individual activity to others over interaction and not every kind of action, even if overt action it is not social if it is oriented solely to the behavior of inanimate objects. For example religious behavior is not social if it is simply a matter of contemplation or of solitary prayer. ${ }^{4}$ Weber maintained that the subject matter of sociological science is "social action" defined as any action (or intentional behavior) whose subjective meaning takes into account the behavior of others and is thereby oriented in its course" 5

For instance, browsing the web is not a social behavior if we are not communicating with others through Chat Box or contributing with content through wiki sites.

From those two concepts about what means social, Christian Fuchs approaches users activities to these understanding where he describes the web 1.0 as a Durkheimian's concept (Social fact) on the grounds that users of web 1.0 where only reading web without interacting with other users then in the second generation of web (social web) we can approach the Weberian concept in the understanding of the social character of web 2.0 where we cannot describe any act that it is social if it is not associates to user's activities and behaviors through a symbolic interaction.

\section{${ }^{*}$ A new web with a new feature:}

When we talk about a new web we mean the web 3.0 where we are describing a web platform more participative and more collaborative, we are talking about a tool that helps users to build communities and to co_operate in creating contents through social networks sites and other applications. This meaning of the character of web3.0 we can associate it to the Marxian concept about co_operation and Tonniesien concept about community_building, (according to Christian Fuchs).

\footnotetext{
1 lbid. p95.

2 Christians Fuchs, Social media a critical introduction, sage, London, 2014, p38.

3 John D.Grennwood, Op_cit, p97.

${ }^{4}$ Christian Fuchs, information and communication technologies and society ( a contribution to the critique of the political economy of the internet), Op_cit, p100.

${ }_{5}$ John D.Grennwood, Op_cit, p100.
} 
Web 3.0 technologies like Wikis are not only communicative but also co_operative, web3.0 reflects an understanding of the social as co_operating that can be traced back in its most pure form to the work of Marx. For Marx and Angels co_operating is the essence of the social: by social we understand the co_operating of several individuals, no matter under what conditions, in what manner and to what end, it follows from this that a certain mode of production, or industrial stage is always combined with a certain mode of co_operation, or social stage, and this mode of co_operating is itself a productive force. ${ }^{1}$

About community building, web 3.0 is a tool for communities building and this concept was discussed by Tonnies, by which he understands the "consciousness of belonging together and the affirmation of the condition of mutual dependence"2

Through those three social conceptual approaches for the web we can conclude three features for each stage of the web, where the web1.0 constitutes a cognition tool where people used it as a source of information and knowledge while the web2.0 was a tool of human communication where the communication act appear in more than one form (from one to one, One to all, All to all). The web 3.0 takes the character of co_operation.

According to this classification we conclude that the web pass over communicational stages which has changed and developed from web to other, this affect also the practical side which concern the relation between users and internet that is transit from read (consumption) to read and write (production), where users integrate in the process of production and participation as well consumption, browsing the internet content, blogging, using tag words, publishing, sharing and thus it becomes an active role for the consumer in producing goods. ${ }^{3}$

These goods (or contents) could be published as texts, photos, videos or could be personal information that users display in their profiles from which they answer to some questions concern age, gender, location, ethnicity, sexual orientation, incomes ...etc ${ }^{4}$

\section{5- Social network sites and social capital:}

\section{*Social Network: from metaphorical/analytic to the modern concept:}

Social networks sites, social networking sites or online social networks. So many concepts to define one meaning this is why is it important to identify the right concept since the other concepts are using two describe another networking act. The most right concept to describe the main tool in web 2.0 application is social network sites and it is

\footnotetext{
${ }^{1}$ Christian Fuchs, information and communication technologies and society( a contribution to the critique of the political economy of the internet), Op_cit, p100

${ }^{2}$ Christian Fuchs, Social networking sites and the surveillance society, Acritical case study of the usage of studiVZ, Facebook, and Myspace by students in Sakzburg in the context of electronic surveillance, 2009, Austria, p5.

${ }^{3}$ David Beer, Roger Burrows, Sociology and, of and in web 2.0 : some initial considerations, http://www.socresonline.org.uk/12/5/17.html, seen in 18/02/2015, 19:44.

${ }^{4}$ Ibid.
} 
also the correct concept which represent a modern concept since there is classical social network which was studied by sociologists, anthropologists, mathematicians and also by computer scientists but the new concept of social networks means according to Danah Boyd and Nicole B.Ellison: "social networks sites are web based services that allow individuals to construct a public or a semi public profile within a bounded system, articulate a list of other users with whom they share a connection and view and traverse their list of connections and those made by others within the system. The nature and nomenclature of these connections may vary from site to site". 1

This definition was the most definition quoted by all studies that concern social network researches and in the same study the two researchers have clarified the deference between social network sites and social networking sites because the term networking emphasizes relationship initiation, often between strangers while networking is possible on these sites, it is not the primary practice on many of them, nor is it what differentiates them from other forms of computer mediated communication (CMC). ${ }^{2}$

Returning to the classical concept of social networks which could be metaphorical or analytic we found that the term (social network) has been discussed in various research grounds like sociology, Anthropology, Mathematic and recently computer sciences, the first use of the concept was metaphorical before giving it, an analytic aspect with the invention of sociometry method that enables analyzing classical social networks with representing them by sociograms for one social unit or group and their relation with other units or other groups where individuals are represented by nodes and the relations that combine them with lines.

In 1934 Jacob L.Moreno specialized in psychology with Helen Hall Jennings have explained How do social relations affect the psychological comfort? Using the sociometry technique as a quantitative method to study the structure of groups and the situation of individuals in these groups, they have used sociograms that represent individuals or social units and their relation with other groups by nodes and lines that combine them. ${ }^{3}$ Moreno laid out a dictionary of network terms; many still used it in the same way today. More important, the sociogram, a visual technique that graphed the ties between social actors, became the main analytical tool of sociometry. For the first time, these pictures of social relationships made clear the structure of friendships, leadership and classrooms. Each individual was represented by a circle with lines showing connections and arrowheads indicating whether the tie was sent or received. ${ }^{4}$

\footnotetext{
${ }^{1}$ Danah M.Boyd \& Nicole B.Ellison, Social Networks Sites (Definition, history and scholarship), Journal of computer-mediated communication, 13(2008), 2008, international communication association, p211.

2 Ibid, p211.

${ }^{3}$ Christina Prell, Social network analysis (history, theory and methodology), Sage, London, 2012 , p29.

${ }^{4}$ Bernice A.Pescosolodo, the sociology of social networks, http://www.uk.sagepub.com/leonguerrero4e/study/materials/reference/05434 socnet.pdf, viewed 11.05.2015, 02.43, p209.
} 


\section{Representation}

- Sociogram
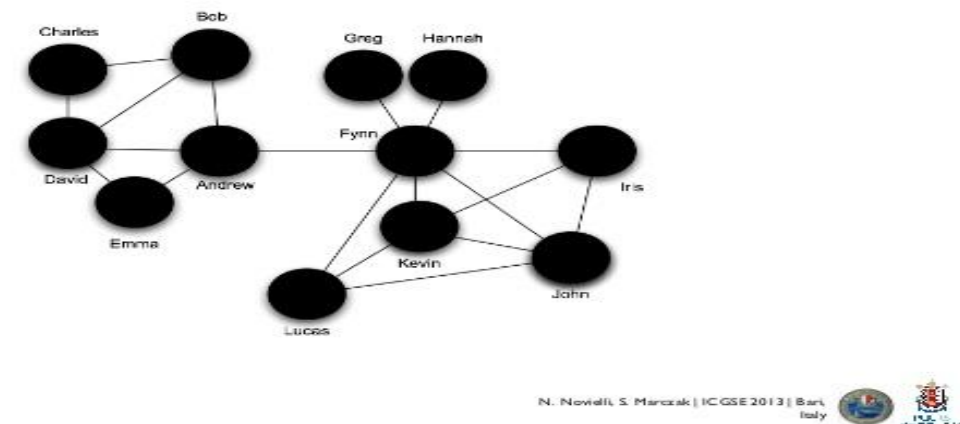

Figure.1 Representation of Network Ties in a Sociogram ${ }^{1}$

In 1954 John A.Barnes study the link between people who live in Norwegian and island Parish, He saw that social interaction represented by a couple of nodes and lines formed a general network and unorganized group of personal relation that formed a micro_network in the whole, Barnes consists his work on Moreno's work who have developed social grams describing what children like/dislike from their colleague's school. ${ }^{2}$ Barnes from the school of Manchester was the first that use the word "Social network" is social sciences field to describe a group of individuals. He analyses the social organization of small community and the deferent relations that combine them. ${ }^{3}$

Radcliff Brown in 1654 in his conceptualization for the social structure, he define social structure as a network of actual social relations where he used a metaphorical concept of network. He has described a complicated and interconnected image for social relations. Radcliff Brown was a lecturer on social relation and its structure where he was searching for the nature of social structure, social relation and society. He has seen the society as a complicated network of relations.

Radcliffe Brown argued that society developed certain structures naturally in efforts to fulfill certain functions, he emphasizes on the role of social relations, he argued that society could be seen as a "complex network" of social relations that he labeled a social structure. ${ }^{4}$

\footnotetext{
${ }^{1}$ Nicole Noveielle \& Sabrina Marczak, Social network analysis for global software engineering, exploring relationship from a fine Grained level, http://fr.slideshare.net/nolli82/social-network-analysis-for-global-softwareengineering-exploring-relationships-from-a-finegrained-level-icgse-2013.

2 David Knocke \& Song yang, Social Network Analysis (Quantitative applications in the social sciences),

Sage, $2^{\text {nd }}$ edition, N154, 2008, p9.

${ }^{3}$ Alya Mlaiki, Comprehension de la continuite d'utilisation des reseaux sociaux numériques : les apports de la théorie du don, Thèse pour l'obtention du titre de doctuer en sciences de gestion, Universiète Paris_Dauhphine, 2012, p40.

4 James Clyde Mitchel, Social networks in urban situations (Analyses of personal relationships in central African touns), Oxford, The university press, 1971, p2
} 
White Harrison (1970) and his colleagues developed new principles to rethink the analysis of network data, using matrix algebra and clustering techniques, block modeling, but the development of the Harvard school represented more than an answer to an analytical problem. It began a resurgence of theoretical interest in sociology that was limited to neither the kinds of data nor the analytical techniques developed by white and his colleagues ${ }^{1}$.

\section{Sociomatrix (Scott, 2000)}

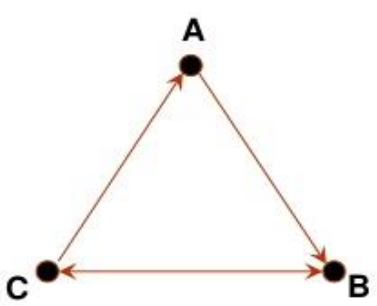

\begin{tabular}{|l|l|l|l|}
\hline & A & B & C \\
\hline A & - & 1 & 0 \\
\hline B & 0 & - & 1 \\
\hline C & 1 & 1 & - \\
\hline
\end{tabular}

Figure 2: Representation of Network Ties with a Sociomatrix. ${ }^{2}$

1 Bernice A.Pescosolodo, Op_cit, p209.

2 Matthew Hendrickson \& Brock Tibert, Social network analysis and interstate mobility,

http://fr.slideshare.net/mjhendrickson/social-network-analysis-and-interstate-mobility 


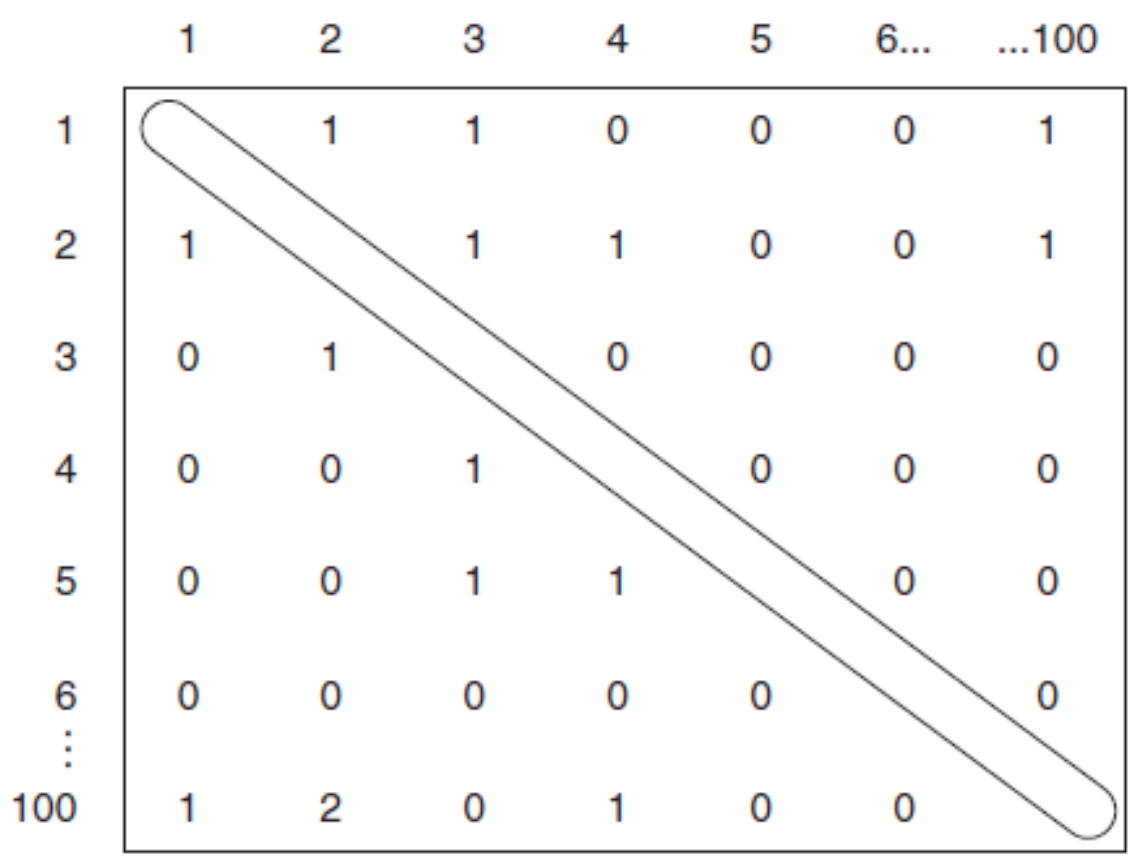

Figure 3: Representation of Network Ties with a Sociomatrix. ${ }^{1}$

Mark Granovetter in social economy as a new field on sociology in the mid of $90^{\text {th }}$ (1970) he present his first contribution in one book about "how people in the work market get information about job's opportunities, where he used social network method and explain how information transformed from the employer to people who are searching for it. The domain of social network analysis looks to social organization among the terminology of network theory to describe the forming of groups. One of the principle concepts in social network analysis is weak ties, or the strength of weak ties which describe unestablished and unorganized relations between individuals. ${ }^{2}$ He identifies the importance of social network in the functioning of the market counter to the law of supply and demand.

\section{*Definition of Social Capital:}

The new communicative tools have created a new era for individuals to communicate not just with their friends but also with new people that they share with them the same interests, thus helps them to create new relationship where the weak ties become an important element in the online social relations.

Before we start the discussion about social capital we will give a definition for the term capital so what is capital?

1 Bernice A.Pescosolodo, Opcit,_p212.

${ }^{2}$ Richard Swedeberg, Principles of economic sociology, USA, Princeton university press, 2003, p96 
Capital is the outcome of a production process (producing or adding value to a resource, in the other, it is the causal factor in a production (the resource is exchanged to generate a profit). ${ }^{1}$ The notion of Capital can be traced to Marx (1849) in his analysis of how capital emerges from social relations between the bourgeoisie (capitalists) and the processes of commodity production and consumption. ${ }^{2}$

The term Social Capital has known an ambiguous discussion between scholars. This term has been widely used to refer to the accumulated resources derived from the relationships among people within a specific social context or network. ${ }^{3}$ There were many researchers that have worked about this concept beginning with Hanifan (1920), Bourdieu (1986), Coleman (1988), Burt (1992), Putnam (2000) and Lin (2001), each one of them gave his own understanding for the concept, for Hanifan: "each individual is in relation with others, this permit the accumulation of social capital, so social capital is a phenomenon sustained by a network of relations between individuals with have a cumulative character through social interactions and the effects are beneficial to an individual and collective level"4, In other definition, Pierre Bourdieu defines Social capital:"the ability of individuals or groups to access resources embedded in their social network. Social capital can be converted to other forms of capital such as favors (human capital) or new information (intellectual capital). ${ }^{5}$

Lin (2001) defines Social Capital as:" investment in social relations with expected returns in the marketplace". ${ }^{6}$

The discussion was not only about the concept but about its elements where there were two frequent debates in the literature involve whether social capital is an individual or collective level phenomenon. According to this Putnam (2000) tends to view social capital as a community level quality, other sociologist like Bourdieu although conceptualizing social capital as a quality of a collective, suggest that individuals possess varying quantities of it by virtue of being qualified members of the collective. ${ }^{7}$ Bourdieu theorizes that" the volume of social capital possessed by a give, agent thus depend on the size of the network of connections he can effectively mobilize and on the volume of the capital possessed in his own right by each of those to whom he is connected. ${ }^{8}$

Through previous definitions we can distinguish the relation between social capital and social network sites. Those sites enable for individuals the access to their social network

\footnotetext{
${ }^{1}$ Nan Lin, Social capital: a theory of social structure and action, Cambridge, Cambridge university press, 2001, p3.

2 lbid, p4.

${ }^{3}$ Charles Steinfield and all, Online social network sites and the concept of social capital,frontiers in new media research, New york, Routledge, 2012, p117.

${ }^{4}$ Alain Cucchi \& Chantal Fuhrer, Capital social et usage des technologies de l'information et de la communication (TIC) : Une analyse par les réseaux sociaux, Management \& avenir, 2011/5 (n 45), p184.

${ }^{5}$ Nicole B.Ellison, Cultivating social resources on social network sites : Facebook relationship maintenance behaviors and their role in social capital processes, Journal of computer-mediated communication, 19, 2014, international communication association, p856.

6 lbid, p856.

7 Ibid, p117.

8 Ibid, p117.
} 
via internet whether the strong or the weak ties, here we found that the classical social network has substituted with the modern social network, and what is deferent here is the possibility for users to maintain and reinforce their offline relationships and in other hand is creating a new online relationship where describe it with weak ties.

Putnam work (2000) conceptualized two distinct forms of social capital, one emanating from weak ties that he called Bridging social capital, and a second that is derived from strong or intimate ties like family relations, called bonding social capital. Bridging social capital is more suited to information diffusion, and is created through exposure to a heterogeneous network of largely weak ties. Bonding social capital represents the kinds of benefits that arise from close relationships within an exclusive group- family and close friends- and is linked to emotional and social support as well as substantive tangible support like financial loans. ${ }^{1}$

The bonding social capital scale likewise was adapted from Williams (2006), tracing its origins to Putnam (2000) it captured the extent to which respondents felt that there were people they could turn to in a time of need within their community for such matters as providing a significant loan, a job reference, to help solve a problem, or to help with other important matters. ${ }^{2}$

Yochai Benkler sees that there are two effects of the internet on social relations:

- First: the thicheening of preexisting relations with friends, family and neighboors, particularly with those who were not easily reachable in the pre_internet_mediated envirenment.

- Second: we are beginning to see the emergence of greater scope for limited_purpose, loose relationships. These may not fit the ideal model of « virtual communities ». They certainly do not fit a deep conception of « community » as a person's primary source of emotional context and support. ${ }^{3}$

Through the presence of society's members on the social network sites they are going to invest in their social capital by strengthening social relations at both sides:

- The first is to create new/virtual relationships with strangers or the so-called weak ties on social capital studies.

- The second dimension is to maintain social relations were already present before they turn into electronic.

\footnotetext{
${ }^{1}$ Charles Steinfield and all,opcit, p4.

2 Ibid, p7.

3 Yochai Benkler, The wealth of networks (How social production transforms markets and freedom), USA,

Yale university press, 2006, p375.
} 
The same thing for Wellman and Gulia 1999 have reviewed prior studies of internet use and social capital concluding that there are three distinct types of findings found in the literature: ${ }^{1}$

- Internet use promotes social capital formation.

- Internet use can diminish social capital

- Internet use reinforces offline interactions and can supplement social capital development.

Today digital social networks have replaced the classic social networks, it plays and represents an important role in the social relation's investment through the creation of social capital that helps individuals to develop themselves and at the same time it has created a new forms of relationships which results the possibility of diminish the offline social relations that have compensated with virtual relationships that can be configured through participation in online groups that their members have common interests.

\section{${ }^{\star}$ References:}

Alain Cucchi \& Chantal Fuhrer, Capital social et usage des technologies de l'information et de la communication (TIC) : Une analyse par les réseaux sociaux, Management \& avenir, 2011/5 (n 45).

Alya Mlaiki, Comprehension de la continuite d'utilisation des reseaux sociaux numériques : les apports de la théorie du don, Thèse pour l'obtention du titre de doctuer en sciences de gestion, Universiète Paris_Dauhphine, 2012.

Bernice A.Pescosolodo, the sociology of social networks, http://www.uk.sagepub.com/leonguerrero4e/study/materials/reference/05434 socnet.pdf.

Charles Steinfield and all, Online social network sites and the concept of social capital,frontiers in new media research, New york, Routledge, 2012, p117.

Christians Fuchs, Social media a critical introduction, sage, London, 2014

Christian Fuchs, information and communication technologies and society ( a contribution to the critique of the political economy of the internet), Sage, European journal of communication, 24(1), 2010.

Christian Fuchs, internet and society (social theory in the information age), New York: Routledge. 2008.

Christian Fuchs, New Media, web2.0 and surveillance, Sociology compass, (5/2), 2011.

Christian Fuhs, Social networking sites and the surveillance society, Acritical case study of the usage of studiVZ, Facebook, and Myspace by students in Sakzburg in the context of electronic surveillance, Austria, 2009.

Christine Greenhown and all, .web2.0 and classroom research: what path should we take now?, American educational researcher association \& sage, 38, may 2009.

Christina Prell, Social network analysis (history, theory and methodology), Sage, London, 2012.

Danah M.Boyd \& Nicole B.Ellison, Social Networks Sites (Definition, history and scholarship), Journal of computer-mediated communication, 13(2008), 2008, international communication association.

Dan Gillmor, We the media (grassroots journalism by the people, for the people), O'Reilly, USA, 2006.

${ }^{1}$ Charles Steinfield and all, opcit, p4. 
David Beer, Roger Burrows, Sociology and, of and in web 2.0: some initial considerations, http://www.socresonline.org.uk/12/5/17.html.

David Knocke \& Song yang, Social Network Analysis (Quantitative applications in the social sciences), Sage, $2^{\text {nd }}$ edition, N154, 2008.

Emile Durkheim, The rules of sociological method, translated by: W.D. Halls, The free press, 1982.

James Clyde Mitchel, Social networks in urban situations (Analyses of personal relationships in central African touns), Oxford, The university press, 1971.

John D. Greenwood, Social facts, social groups and social explanation, NOÛS, $37: 1$ (2003).

Matthew Hendrickson \& Brock Tibert, Social network analysis and interstate mobility, http://fr.slideshare.net/mjhendrickson/social-network-analysis-and-interstate-mobility

Nan Lin, Social capital: a theory of social structure and action, Cambridge, Cambridge university press, 2001

Nicole B.Ellison, Cultivating social resources on social network sites : Facebook relationship maintenance behaviors and their role in social capital processes, Journal of computer-mediated communication, 19,2014 , international communication association.

Nicole Noveielle \& Sabrina Marczak, Social network analysis for global software engineering, exploring relationship from a fine_Grained level, http://fr.slideshare.net/nolli82/social-network-analysis-forglobal-software-engineering-exploring-relationships-from-a-finegrained-level-icgse-2013

Paul Anderson, what is web2.0? (ideas, technologies and implications for education), JISC technology and standards watch, 2007

Richard Swedeberg, Principles of economic sociology, USA, Princeton university press, 2003.

Sarah M. Long, Exploring Web 2.0: The Impact of Digital Communications Technologies on Youth Relationships and Sociability, 2010, sociology student scholarship, http://scholar.oxy.edu/sociology_student/2/?utm_source=scholar.oxy.edu\%2Fsociology_student \%2F2\&utm_medium=PDF\&utm_campaign=PDFCoverPages.

Thomas Chaimbault, Web 2.0 :l'avenir du web, école nationale supérieure des sciences de l'information et des bibliothèques, 2007.

Yochai Benkler, The wealth of networks (How social production transforms markets and freedom), USA, Yale university press, 2006. 